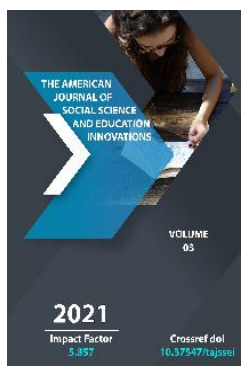

\title{
Theoretical Rationale For Content-Language Integrated Learning (Clil) In Educational Institutions
}

\author{
Tashmatova Gulnara Rafailovna \\ Teacher Of The Department Of The English Language, Faculty Of Foreign Languages, Fergana \\ State University, Fergana City, Republic Of Uzbekistan
}

\begin{abstract}
Journal Website:
http://theamericanjour

nals.com/index.php/taj ssei

Copyright: Original content from this work may be used under the terms of the creative commons attributes 4.0 licence.
\end{abstract}

\section{ABSTRACT}

The article under discussion reveals the issues of theoretical rationale for content-language integrated learning (CLIL) in educational institutions. The author of the article consider that CLIL as an educational approach serves to maintain linguistic diversity as well as a powerful tool that has a significant impact on the process of learning a foreign language. Moreover, CLIL is an innovative approach to learning, creating a holistic, dynamic and stimulating learning environment. The approach under consideration expands didactic possibilities of the traditional educational curriculum, namely, not to teach each subject separately, but to integrate subjects with others.

\section{KEYWORDS}

Content-language integrated learning, linguistic diversity, holistic, dynamic, stimulating, approach, foreign, traditional, educational, curriculum.

\section{INTRODUCTION}

The modern professional community in the context of globalization and internationalization requires specialists to develop the skills of integrative foreign language communication necessary to establish professional and business communication with representatives of other cultures. Consequently, the modern educational system faces the task of developing an interdisciplinary methodology of the educational process, which includes simultaneous teaching of a foreign language (FL) and a professional discipline.

Thus, the goal of teaching a foreign language is not only to develop the ability for intercultural communication, but also to develop the ability for professional communication in a multicultural space.

\section{MAIN PART}


The study of theoretical and methodological foundations of foreign language education of future specialists highlights the development of interdisciplinarity during the improvement of professional competence as a systemforming factor of a foreign language professional education [7, p.357; 8, p.34].

The development of the process of a language and professional discipline integration has led to the formation of the CLIL (contentlanguage integrated learning) approach. CLIL is an innovative approach to bilingual education that involves the simultaneous learning of a foreign language and the content of a professional discipline [3, p.184; 12, p.233]. The term content-language integrated learning (CLIL) was first used by D. Marsh in 1994. According to D. Marsh the term "Content-language integrated learning" (CLIL) can be applied when we are talking about disciplines or certain topics within these disciplines, which are taught in a foreign language and have two objectives: learning the content of the discipline and learning a foreign language at the same time [10, p.205]. It should be noted that this concept has a broad interpretation and more than 40 definitions of content- language integrated learning (CLIL) are used in the European scientific and methodological literature alone.

For example, the definition adopted by the European Commission considers CLIL as a concept in which a foreign language acts as a learning tool. According to the more comprehensive definition by D. Marsh above, CLIL refers to the simultaneous learning of both the discipline and a foreign language itself. Thus, D. Marsh emphasizes that the use of CLIL is aimed at achieving two goals: learning a foreign language and learning a discipline [10, p.210]. Using this idea allows learning a foreign language without devoting additional classroom hours to its direct study, as it acts as a means of teaching other subjects.

D. Graddol believes that the use of CLIL will, first and foremost, allow students to increase significantly their proficiency in foreign languages. D. Graddol believes that a high level of foreign language proficiency is not a prerequisite for mastering the discipline. However, this approach to the interpretation of CLIL has been heavily criticized [6, p.17].

D. Graddol also sees a foreign language, particularly English, as a core skill which allows students to develop communicative skills at a high level. This understanding of CLIL is key in light of the changes that are taking place in education and society in general due to the rapid development of Internet technology and the process of globalization [6, p.23].

According to P. Ball, there are objective reasons why the idea of subject-linguistic integration has a higher motivating potential than others, namely [2, p.16]:

- $\quad$ The need to learn the content of the discipline motivates students to improve their foreign language proficiency;

- A lexical approach is used, through which students notice and analyze language structures and lexical units, for example while reading a text;

- There is an immersion into the language environment, as well as an awareness of the importance of their own achievements in the learning process;

- $\quad$ The content of the discipline becomes particularly important, while in other methods of teaching the foreign language the content of the discipline serves as an illustration of the language structures being studied. 
Many researchers, such as P. Ball [1], S. Darn [15], D. Coyle, P. Hood, D. Marsh [3] and others distinguish two main approaches in the implementation of subject-linguistic integration in the educational process:

- $\quad$ Content-driven education, in which the learning process is focused primarily on learning the content of the academic discipline;

- $\quad$ Language-driven education focuses on learning a foreign language on the basis of subject content.

It should be noted that this division is conditional, and both approaches are used simultaneously, mutually complementing each other. The diagram in the figure shows the main approaches in the implementation of subject-linguistic integration in the learning process.

According to P. Ball, one of the main features of CLIL is the use of "conceptual sequencing", according to which the topics to be studied are presented in a horizontal (or vertical) sequence and are chronologically or thematically dependence [2, p.23].

CLIL is based on the fact that the curriculum disciplines are taught and studied in a foreign language. Thus, this technology is characterized by the fact that:

- $\quad$ Foreign language becomes a way of learning the content of other academic disciplines;

- $\quad$ A foreign language is widely used in the curriculum;

- Increases the motivation of students;

- $\quad$ Students master a foreign language sufficiently after 5 - 7 years of study in a bilingual program;

- $\quad$ Preference is given to fluency rather than correctness of speech, as the presence of grammatical or lexical errors is considered an integral part of the language learning process. Students develop fluency and fluency by using the foreign language as a means of communication;

- $\quad$ The main skill to be formed is reading.

S. Darn [5, p.43] identifies the following benefits of CLIL:

- Use of a broad cultural content;

- $\quad$ Preparing students for the process of internationalization and globalization;

- Expansion of the list of subjects to be studied, along with the opportunity to obtain internationally recognized learning certificates;

- Formation and development of general and special language competences;

- The opportunity to diversify the methods of learning and cognitive activities.

According to the " $4 \mathrm{C}$ " curriculum (Figure 1) developed by D. Coyle in 1999 [4, p.6], a CLILbased foreign language class should include the following elements:

- $\quad$ Content - the acquisition of knowledge as well as the development of skills within the curriculum;

- Communication - using a foreign language to learn and teaching a foreign language at the same time;

- Cognition - the development of cognitive skills, which act as a link between the ability to formulate concepts (abstract or concrete), foreign language and perception of information;

- $\quad$ Cultural component (Culture) implies formation and development of general cultural competence. 


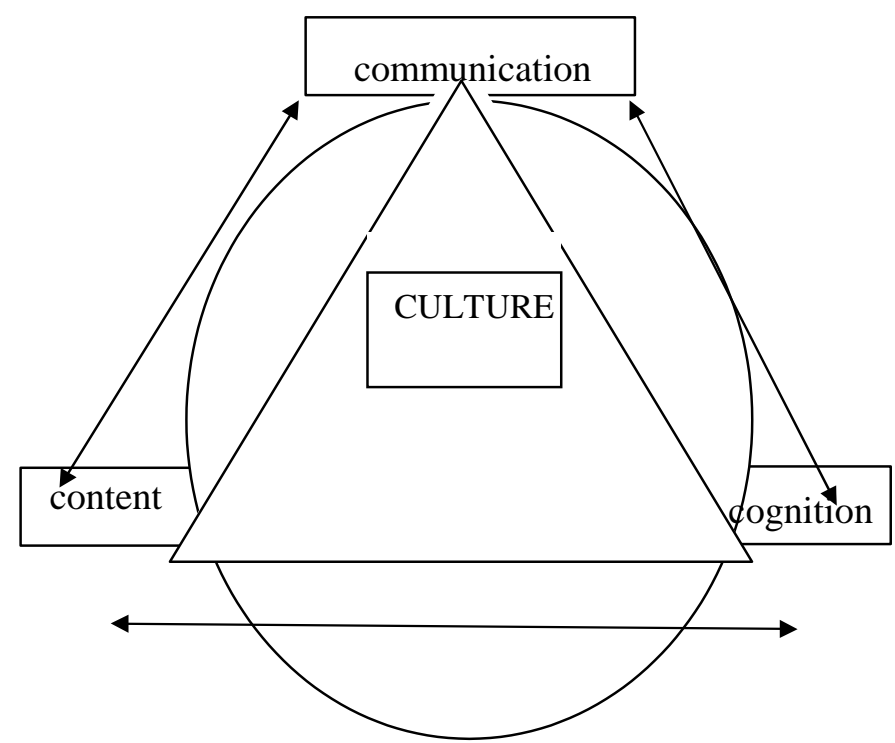

Figure 1. The Pyramid of content-language integrated learning (CLIL)

According to CLIL, as part of a foreign language class it is necessary to develop all types of speech activities. S. Darn believes that from the perspective of a foreign language teacher a CLIL foreign language class should have the following characteristics $[5, \mathrm{p} .8]$ :

- The class should integrate the development of both receptive and productive speech skills;

- $\quad$ The basis of the lesson is usually a text or audio representation of a text;

- $\quad$ The use of language structures and language units is functional and conditioned by the content of the studied discipline;

- $\quad$ The study of a foreign language is based on a lexical rather than a grammatical approach;

- $\quad$ The individual approach is widely used.

\section{CONCLUSION}

Most experts believe that the use of CLIL has great prospects, but its implementation requires a revision of traditional concepts and attitudes towards teaching. At this point, there are a number of circumstances that many researchers believe may have a negative impact on the implementation of CLIL in instruction. Subject teachers are not always willing to support innovations, because the use of this technology requires a lot of teacher training. It should also be noted the small number of programs and trainings for CLIL training and the lack of coordination of foreign language programs with programs in other disciplines. Nevertheless, the need for reform in the field of teaching foreign languages in connection with the process of globalization promotes an active introduction of CLIL technology in the educational systems of most countries in the future.

\section{REFERENCES}

1. Ball, P. How do you know of your practicing CLIL? URL: http://www.onestopenglish.com/clil/m etodologu/- articles/article-how-doyou-know-if-youre-practisingclil/500614.article.

2. Ball, P. What is CLIL? URL : http:www.onestopenglish.com/clil/me thodology/articles/article-what-is-clil/500453.article. 
3. Coyle, D., Hood, P., \& Marsh, D. (2010). Content and language integrated learning. Ernst Klett Sprachen.

4. Darn, S. Content and Language Integrated learning. URL : http:/www.teachingenglish.org.uk/arti cles/content- language-integratedlearning.

5. Graddol, D. English Next, British Council Publications. URL : http://www.britishcouncil.org/learning-research-englishnext.htm.

6. Kobicheva A.M. (2016). The factor of university education in innovative economy of Russia. Audit and financial analysis. Reviewed journal. Issue № 3 Moscow: Publishing house LLC "DSM Press". p.p.357-362.

7. Kobicheva A.M., Baranova T.A., Tokareva E.Yu. Increasing the motivation of students of the direction "Advertising and public relations" in the process of content-language integrated learning (CLIL) // Sophisticated science-intensive technologies. 2019. No. 1. URL: http://www.toptechnologies.ru/ru/article/view?id=373

93.

8. Marsh, D. (2010). Take your brain on a language workout, Learning English. The Guardian Weekly, 15(10), 4.

9. Marsh D. (2002). The Emergence of CLIL in Europe 1958-2002. In E. Kärkkäinen, J. Haynes; T. Lauttamus (Eds.), Studia Linguistics ar Literaria Septentrionalia. Sudies presented to Heikki Nyyssönes. University of Oulu, Finland. P.p. 205-225.

10. Marsh D. (2002). Content and Language Integrated Learning: The European Dimension - Actions, Trends and Foresight Potential. - Cambridge University Press. P.552.
11. Marsh D. (2007). Language Awareness and CLIL. In J. Cenoz; N.H. Hornberger (Eds.), Encyclopedia of Language and Education. Knowledge about Language, 2nd edition, Volume 6 . New York: Springer Science and Business Media LLC. P.p. 233- 246.

12. Marsh, D. (2001). Integrating Competencies for Working Life. D. Marsh, B. Marsland, K. Stenberg. Jyväskylä : University of Jyväskylä,. P.262.

13. Marsh, D. Project D3 - CIIL Matrix Central workshop 6/2005 // European Centre for Modern Languages. URL : http://archive.ecml.at/mtp2/CLILmatrix /pdf/wsrepD3E2006_6.pdf.

14. Marsh, D. (2001). Profiling European CLIL Classrooms: Languages Open Doors / D. Marsh, A. Maljers. Jyväskylä : University of Jyväskylä,. P.253.

15. Marsh, D. (2000). Using Languages to Learn and Learning to Use Languages. D. Marsh. Jyväskylä : University of Jyväskylä,. - P.156. 